\title{
A REVIEW OF 112 CASES OF CONGENITAL HYPERTROPHIC PYLORIC STENOSIS*
}

\author{
BY \\ R. MCLAREN TODD, M.A., M.D., M.R.C.P., D.C.H. \\ Medical Registrar, Queen Elizabeth Hospital for Children, London ; Late R.M.O., Leicester \\ Royal Infirmary
}

\section{Congenital Pyloric Stenosis}

Congenital hypertrophic pyloric stenosis is one of the common diseases encountered during the first few weeks of life. When a survey of the literature is made, the wide variation of mortality rate reported both with medical and surgical treatment is striking. An attempt has been made to discover the factors which determined the success or failure of the treatment adopted; from records of various observers, it appeared that one of the main causes of failure was inadequate attention to the details of treatment. During a two-and-a-half-year period, a study was made of forty cases (Series A) of congenital pyloric stenosis treated in the wards and out-patient department of the Leicester Royal Infirmary, a hospital at which a detailed routine method of treatment has been employed for the past ten years. After a period of time varying from one year to two and a half years the cases were reviewed with particular reference to any physical or mental defects which could be attributed to this disease. For this purpose the children were readmitted to hospital for a detailed clinical examination and for a radiological examination of the stomach. A further series of seventy-two cases (Series B) of congenital

\footnotetext{
* Part of thesis, Degree of M.D., University of Cambridge, August, 1946.
}

pyloric stenosis covering an eight-year period (1938 to 1945) were also followed up clinically. Some of these had a radiological examination of the stomach.

From a study of these 112 cases, certain conclusions as to treatment are drawn and some interesting results of the radiological follow-up are recorded.

\section{Clinical Material}

The clinical material consisted of 112 cases treated in the wards and out-patient department of a provincial general hospital serving a population of some 550,000 people. Details of the yearly incidence, etc., are found in table 1 . Every case reported was diagnosed as a case of congenital stenosis on the following evidence: (a) history of projectile vomiting, constipation and, usually, loss of weight; (b) visible gastric peristalsis; (c) palpable pyloric tumour. Confirmatory evidence in the form of barium x-ray examination was only undertaken in the year 1938 (eight cases); in the remaining 104 cases the presence of a palpable pyloric tumour was taken as positive evidence of the disease without x-ray confirmation.

The average age of onset of symptoms was twenty-six days and the duration of symptoms before onset of treatment was fifteen days; thus at the beginning of treatment the average age was forty-one days. The average weight when treatment

TABLE 1

YEARLY INCIDENCE OF CONGENITAL PYLORIC STENOSIS TREATED IN THE WARDS AND OUT-PATIENT DEPARTMENT OF A PROVINCIAL GENERAL HOSPITAL

\begin{tabular}{lll|r|r|r|r|r|r|r|r}
\hline & & 1938 & 1939 & 1940 & 1941 & 1942 & 1943 & 1944 & 1945 \\
\hline Total new out-patients .. &. &. & 19,458 & 19,288 & 20,578 & 24,739 & 26,394 & 29,093 & 20,532 & 21,782 \\
Total children's out-patients &. &. & 386 & 392 & 456 & 514 & 512 & 542 & 533 & 558 \\
Total in-patients &.. &. & 9,676 & 9,372 & 9,794 & 11,571 & 11,962 & 12,141 & 13,178 & 14,028 \\
Total children's in-patients &. &. & 407 & 431 & 473 & 482 & 484 & 532 & 513 & 615 \\
Cases of pyloric stenosis &. &. & 8 & 9 & 11 & 10 & 18 & 16 & 21 & 19 \\
Deaths from pyloric stenosis &. &. & 0 & 0 & 2 & 2 & 2 & 0 & 2 & 4 \\
Barium meals follow-up &. &. & 3 & 4 & 2 & 2 & 9 & 16 & 10 & 0 \\
\hline
\end{tabular}


TABLE 2

SERIES A: CASES GROUPED ACCORDING TO DURATION OF STAY IN HOSPITAL

\begin{tabular}{|c|c|c|c|c|c|c|c|c|c|c|c|}
\hline \multirow{5}{*}{$\begin{array}{l}\text { Group A: in hos- } \\
\text { pital ten days } \\
\text { or less }\end{array}$} & Case & Sex & $\begin{array}{c}\text { Place in } \\
\text { family }\end{array}$ & $\begin{array}{c}\text { Days } \\
\text { in } \\
\text { hospital }\end{array}$ & $\begin{array}{c}\text { Age at } \\
\text { onset } \\
\text { (weeks) }\end{array}$ & $\begin{array}{l}\text { Age on } \\
\text { admis- } \\
\text { sion in } \\
\text { weeks }\end{array}$ & $\begin{array}{l}\text { Dura- } \\
\text { tion in } \\
\text { weeks }\end{array}$ & $\begin{array}{l}\text { Change } \\
\text { from } \\
\text { birth } \\
\text { weight } \\
\pm \mathrm{oz} .\end{array}$ & $\begin{array}{l}\text { Dose of } \\
\text { eumy- } \\
\text { drin in } \\
\text { c.cm. }\end{array}$ & $\begin{array}{l}\text { Dura- } \\
\text { tion of } \\
\text { eumy- } \\
\text { drin in } \\
\text { days }\end{array}$ & $\begin{array}{l}\text { Gain in } \\
\text { oz. } \\
\text { weight } \\
\text { on dis- } \\
\text { charge }\end{array}$ \\
\hline & 10 & $\mathbf{M}$ & 2 (1st & 2 & 5 & 7 & 2 & -16 & 3 & 28 & 2 \\
\hline & $\begin{array}{l}10 \\
14 \\
22\end{array}$ & $\begin{array}{l}\mathbf{F} \\
\mathbf{M} \\
\mathbf{M}\end{array}$ & $\begin{array}{c}1 \\
1 \\
3 \text { (1st } \\
\text { boy) }\end{array}$ & $\begin{array}{l}9 \\
6 \\
8\end{array}$ & $\begin{array}{l}3 \\
6 \\
4\end{array}$ & $\begin{array}{l}4 \\
8 \\
8\end{array}$ & $\begin{array}{l}1 \\
2 \\
4\end{array}$ & $\begin{array}{l}-5 \\
-3 \\
-6\end{array}$ & $\begin{array}{l}3 \\
3 \\
3\end{array}$ & $\begin{array}{l}34 \\
42 \\
23\end{array}$ & $\begin{array}{l}3 \\
9 \\
5\end{array}$ \\
\hline & 24 & $F$ & 2 & 10 & 2 & 4 & 2 & -31 & 3 & 13 & 7 \\
\hline & \multicolumn{3}{|c|}{$\begin{array}{l}\text { Average in five } \\
\text { cases }\end{array}$} & 7 & 4 & $6 \cdot 2$ & $2 \cdot 2$ & $-12 \cdot 2$ & 3 & 28 & $5 \cdot 2$ \\
\hline \multirow{4}{*}{$\begin{array}{l}\text { Group B: in hos- } \\
\text { pital eleven to } \\
\text { twenty days }\end{array}$} & 6 & $\mathbf{M}$ & $\begin{array}{l}5 \text { (4th } \\
\text { bov) }\end{array}$ & 19 & 2 & 3 & 1 & -12 & 5 & 18 & 14 \\
\hline & $\begin{array}{l}13 \\
15 \\
18 \\
21 \\
23 \\
26 \\
27\end{array}$ & $\begin{array}{l}\mathbf{M} \\
\mathbf{F} \\
\mathbf{M} \\
\mathbf{F} \\
\mathbf{F} \\
\mathbf{M} \\
\mathbf{M}\end{array}$ & $\begin{array}{c}1 \\
4 \\
4 \\
1 \text { (twin) } \\
1 \\
2 \\
1\end{array}$ & $\begin{array}{l}15 \\
19 \\
14 \\
12 \\
14 \\
11 \\
12\end{array}$ & $\begin{array}{l}6 \\
1 \\
5 \\
4 \\
4 \\
2 \\
5\end{array}$ & $\begin{array}{l}6 \\
3 \\
6 \\
5 \\
5 \\
3 \\
9\end{array}$ & $\begin{array}{c}2 \text { days } \\
2 \\
1 \\
1 \\
1 \\
1 \\
4\end{array}$ & $\begin{array}{l}-19 \\
-2 \\
-5 \\
+8 \\
+1 \frac{1}{2} \\
-14 \\
+8\end{array}$ & $\begin{array}{c}3 \\
3 \\
3 \\
1 \\
3-4 \\
3 \\
\text { Tras- }\end{array}$ & $\begin{array}{l}42 \\
21 \\
28 \\
12 \\
26 \\
18 \\
11\end{array}$ & $\begin{array}{c}3 \\
21 \\
9 \frac{1}{2} \\
9 \\
15 \\
7 \frac{1}{2} \\
18\end{array}$ \\
\hline & 29 & $\mathbf{M}$ & 5 & 20 & 1 & 6 & 5 & -11 & 4 & 18 & $11 \frac{1}{2}$ \\
\hline & \multicolumn{3}{|c|}{$\begin{array}{l}\text { Average in nine } \\
\text { cases }\end{array}$} & 15 & $3 \cdot 3$ & $5 \cdot 1$ & $1 \cdot 8$ & $-5 \cdot 1$ & 3 & 22 & 12 \\
\hline \multirow[t]{2}{*}{$\begin{array}{l}\text { Group C: in hos- } \\
\text { pital twenty- } \\
\text { one to thirty } \\
\text { days }\end{array}$} & $\begin{array}{r}1 \\
4 \\
5 \\
8 \\
9 \\
12 \\
16 \\
19\end{array}$ & $\begin{array}{l}\mathbf{M} \\
\mathbf{M} \\
\mathbf{M} \\
\mathbf{M} \\
\mathbf{M} \\
\mathbf{M} \\
\mathbf{M} \\
\mathbf{M}\end{array}$ & $\begin{array}{l}3 \\
1 \\
1 \\
1 \\
1 \\
1 \\
1 \\
1\end{array}$ & $\begin{array}{l}26 \\
24 \\
27 \\
25 \\
25 \\
22 \\
29 \\
29\end{array}$ & $\begin{array}{l}3 \\
2 \\
2 \\
2 \\
6 \\
3 \\
4 \\
2\end{array}$ & $\begin{array}{l}4 \\
4 \\
3 \\
3 \\
7 \\
3 \\
5 \\
2\end{array}$ & $\begin{array}{c}1 \\
2 \\
1 \\
1 \\
1 \\
3 \text { days } \\
1 \\
2 \text { days } \\
\end{array}$ & $\begin{array}{l}+10 \\
-20 \\
-12 \\
-13 \\
+22 \\
-12 \\
-26 \\
-9\end{array}$ & $\begin{array}{c}3-5 \\
3 \\
3-5 \\
3 \\
3 \\
3-5 \\
3-5 \\
3-5-8\end{array}$ & $\begin{array}{r}17 \\
22 \\
8 \\
29 \\
16 \\
21 \\
35 \\
10 \\
\end{array}$ & $\begin{array}{c}15 \\
12 \\
4 \mathrm{R} \\
21 \\
9 \\
10 \\
16 \\
12 \mathrm{R} \\
\end{array}$ \\
\hline & \multicolumn{3}{|c|}{$\begin{array}{l}\text { Average in eight } \\
\text { cases }\end{array}$} & 26 & 3 & 4 & 1 & $-7 \cdot 5$ & $3 \cdot 5$ & 20 & 12 \\
\hline \multirow[t]{2}{*}{$\begin{array}{l}\text { Group D: in hos- } \\
\text { pital over thirty } \\
\text { days }\end{array}$} & $\begin{array}{r}2 \\
3 \\
7 \\
25 \\
28 \\
30\end{array}$ & $\begin{array}{l}\mathbf{M} \\
\mathbf{M} \\
\mathbf{M} \\
\mathbf{M} \\
\mathbf{M} \\
\mathbf{M}\end{array}$ & $\begin{array}{l}1 \\
1 \\
1 \\
5 \\
1 \\
1\end{array}$ & $\begin{array}{l}40 \\
38 \\
48 \\
38 \\
36 \\
30\end{array}$ & $\begin{array}{l}4 \\
2 \\
4 \\
2 \\
2 \\
5\end{array}$ & $\begin{array}{l}4 \\
3 \\
6 \\
6 \\
3 \\
7\end{array}$ & $\begin{array}{c}1 \text { day } \\
1 \\
2 \\
4 \\
1 \\
2\end{array}$ & $\begin{array}{l}-4 \\
-43 \\
+12 \\
-56 \\
-13 \\
-24\end{array}$ & $\begin{array}{c}3-5 \\
5 \\
3-5 \\
3 \\
3-5 \\
3-4-5\end{array}$ & $\begin{array}{l}36 \\
28 \\
46 \\
36 \\
50 \\
80\end{array}$ & $\begin{array}{l}15 \\
21 \\
20 \\
15 \\
11 \\
33 \\
\end{array}$ \\
\hline & \multicolumn{3}{|c|}{$\begin{array}{l}\text { Average in six } \\
\text { cases }\end{array}$} & 38 & $3 \cdot 1$ & $4 \cdot 8$ & $1 \cdot 7$ & -21 & 4 & 46 & 19 \\
\hline
\end{tabular}


TABLE 2 (continued)

\begin{tabular}{|c|c|c|c|c|c|c|c|c|c|c|}
\hline & Case & Sex & $\begin{array}{c}\text { Place } \\
\text { in } \\
\text { family }\end{array}$ & $\begin{array}{c}\text { Age at } \\
\text { onset } \\
\text { (weeks) }\end{array}$ & $\begin{array}{c}\text { Age at } \\
\text { first } \\
\text { visit } \\
\text { (weeks) }\end{array}$ & $\begin{array}{l}\text { Dura- } \\
\text { tion in } \\
\text { weeks }\end{array}$ & $\begin{array}{c}\text { Change } \\
\text { from } \\
\text { birth } \\
\text { weight } \\
\pm \text { oz. }\end{array}$ & $\begin{array}{l}\text { Dose of } \\
\text { eumy- } \\
\text { drin in } \\
\text { c.cm. }\end{array}$ & $\begin{array}{l}\text { Dura- } \\
\text { tion } \\
\text { eumy- } \\
\text { drin in } \\
\text { weeks }\end{array}$ & $\begin{array}{l}\text { Gain in } \\
\text { oz. } \\
\text { weight } \\
\text { on dis- } \\
\text { charge }\end{array}$ \\
\hline \multirow[t]{2}{*}{$\begin{array}{l}\text { Group E: out-patient } \\
\text { treatment }\end{array}$} & $\begin{array}{l}31 \\
32 \\
33 \\
34 \\
35 \\
36 \\
37 \\
38 \\
39 \\
40\end{array}$ & $\begin{array}{l}\mathbf{F} \\
\mathbf{F} \\
\mathbf{F} \\
\mathbf{M} \\
\mathbf{M} \\
\mathbf{M} \\
\mathbf{M} \\
\mathbf{M} \\
\mathbf{M} \\
\mathbf{M}\end{array}$ & $\begin{array}{l}1 \\
1 \\
2 \\
1 \\
1 \\
3 \\
1 \\
3 \\
2 \\
1\end{array}$ & $\begin{array}{l}6 \\
6 \\
8 \\
4 \\
1 \\
1 \\
6 \\
3 \\
5 \\
2\end{array}$ & $\begin{array}{r}10 \\
8 \\
11 \\
5 \\
6 \\
3 \\
8 \\
12 \\
7 \\
12\end{array}$ & $\begin{array}{r}4 \\
2 \\
3 \\
1 \\
5 \\
2 \\
2 \\
9 \\
2 \\
10\end{array}$ & $\begin{array}{l}+16 \\
+25 \\
-26 \\
+8 \\
+32 \\
-2 \\
+36 \\
+2 \\
+12 \frac{1}{2} \\
+62\end{array}$ & $\begin{array}{c}3 \\
5-7 \\
3 \\
3 \\
3 \\
3 \\
3 \\
3 \\
3 \\
3\end{array}$ & $\begin{array}{l}4 \\
8 \\
4 \\
3 \\
5 \\
6 \\
4 \\
5 \\
5 \\
5\end{array}$ & $\begin{array}{l}56 \\
64 \\
26 \\
24 \\
64 \\
64 \\
30 \\
54 \\
38 \\
60\end{array}$ \\
\hline & \multicolumn{3}{|c|}{$\begin{array}{l}\text { Average in ten } \\
\text { cases }\end{array}$} & $4 \cdot 2$ & $8 \cdot 2$ & 4 & $+16 \cdot 5$ & 3 & $4 \cdot 9$ & 48 \\
\hline
\end{tabular}

was begun was $7 \mathrm{lb}$. and the average gain in weight was $4 \frac{1}{2}$ oz. per week.

Routine treatment. The mothers of breast-fed babies came into hospital with them and were responsible for the feeding under the supervision of the sister of the ward. The routine food for artificially-fed babies was half-cream Cow and Gate. The volume and strength of the feeds were the same as for normal babies. Feeds were given threehourly, and eumydrin, 1 in 10,000 aqueous solution, was given half an hour before each feed. The initial dose was $3 \mathrm{c.cm} .(0 \cdot 3 \mathrm{mg}$.) and this was increased to 4,5 , or $6 \mathrm{c.cm}$. if vomiting continued. In dehydrated babies subcutaneous salines were given until dehydration was relieved, and then eumydrin was begun. The solution used for subcutaneous injection was 4 per cent. glucose in 0.18 normal saline, $50 \mathrm{c.cm}$. being given into each axilla or groin twice daily and once at night. It was found that the fluid had absorbed within three hours, and, by using the groins and axillae alternately, these sites of injection could be used until the dehydration was relieved. No skin sepsis and no persistence of oedema was encountered. The needles used were $8 / 10 \mathrm{~mm}$. bore with record ends attached to a $20 \mathrm{c} . \mathrm{cm}$. syringe. Ether was used for skin cleansing, wool and collodion were used locally after the injection was completed, and the area was treated as a surgical dressing.

Stomach washouts were given twice daily until there was no gastric residue. A number 5 Jaques catheter with tube and funnel attached was used through the mouth, and a funnel-full of fluid ( $2 \frac{1}{2} \mathrm{oz}$.) was given at a time until about 2 pints had been used to wash out the stomach. The solution consisted of $2 \mathrm{oz}$. normal saline in 2 pints of water. The average duration of stomach washouts was seven days. If severe constipation was present, rectal washouts were given about every third day until the bowels acted more regularly. If vomiting had been excessive before admission, ammonium chloride ( 2 gr. three times a day) was given to combat the alkalosis.

Every case was treated in a single cubicle so that cross infection was cut down to a minimum.

SERIES A. Thirty-eight of the forty cases were treated with eumydrin or other antispasmodic, and the remaining two cases (numbers 5 and 19) were subjected to Rammstedt's operation after a trial of eumydrin. Two cases (numbers 17 and 20) died while under treatment, number 17 being moribund on admission and dying within forty-eight hours, and number 20 dying of gastro-enteritis within twenty-four hours of readmission to hospital after having been previously treated successfully. Cases 15 and 26 were readmitted to hospital about two months after the pyloric stenosis had been cured, case 15 dying of a rapidly-growing retro-peritoneal sarcoma, and case 26 from a right-sided pneumococcal empyema and left pneumothorax.

Thus, of these forty cases, thirty-six responded to eumydrin, two responded to Rammstedt's operation after eumydrin had failed to relieve the symptoms, and two cases died-a mortality rate of 5 per cent. In table 2 the cases are divided into four groups depending on the duration of hospital treatment, and a fifth group consists of the cases treated entirely as out-patients. The two cases that died are not included, but are considered separately.

It has been pointed out by many observers that cases of congenital pyloric stenosis will recover spontaneously in time if death does not take place in the process. With eumydrin treatment Dobbs (1941) has emphasized that older babies respond more readily than younger ones. Mackay's (1941) series of forty "cases also supports this view. The average age of onset of groups A and E of this series is four weeks, whereas in the other groups three weeks is the average time. Again in group E there was an average of $16 \mathrm{oz}$. above the birth weight 
TABLE 3

SERIES B: CASES GROUPED ACCORDING TO DURATION OF STAY IN HOSPITAL

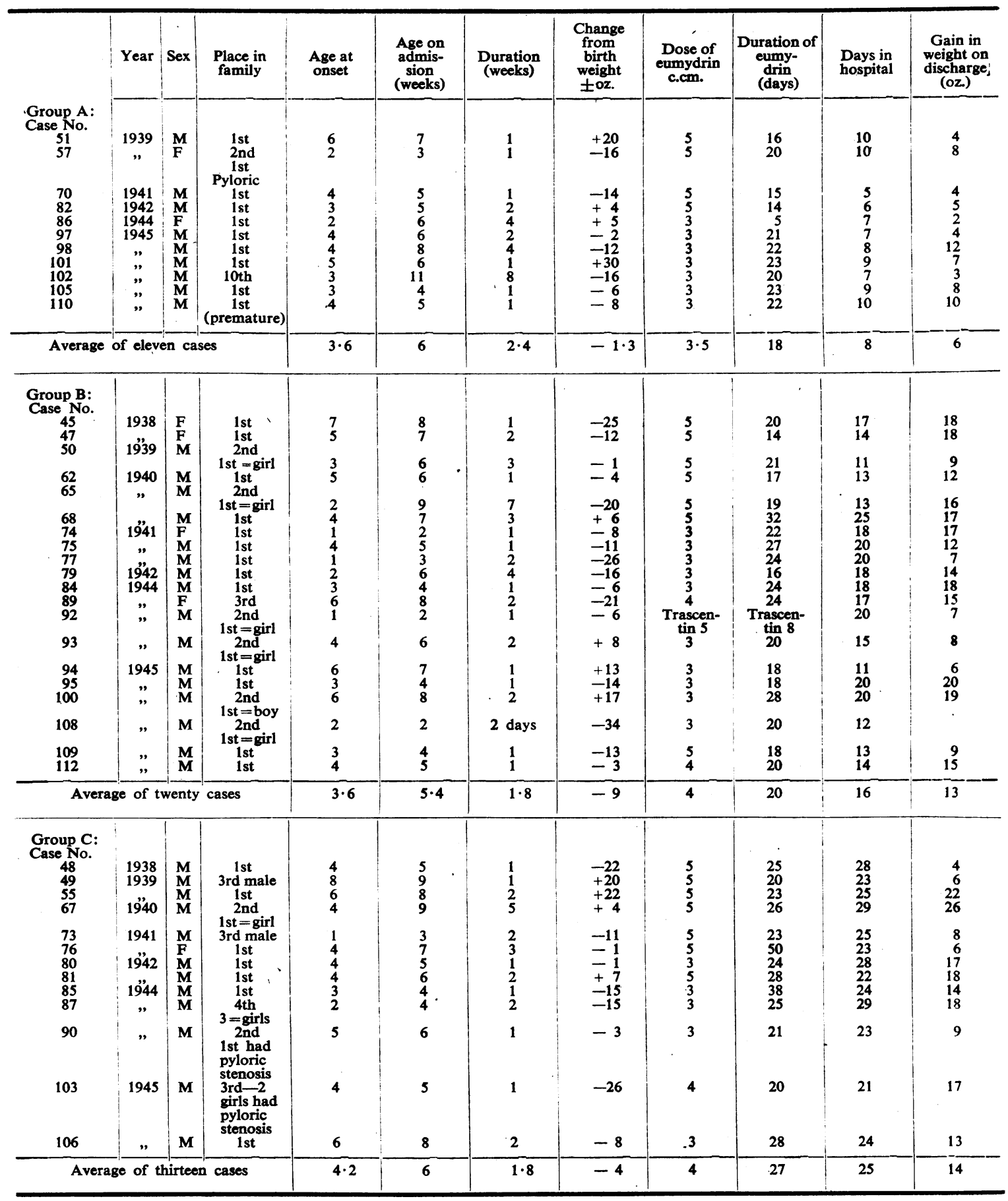


Table 3 (continued)

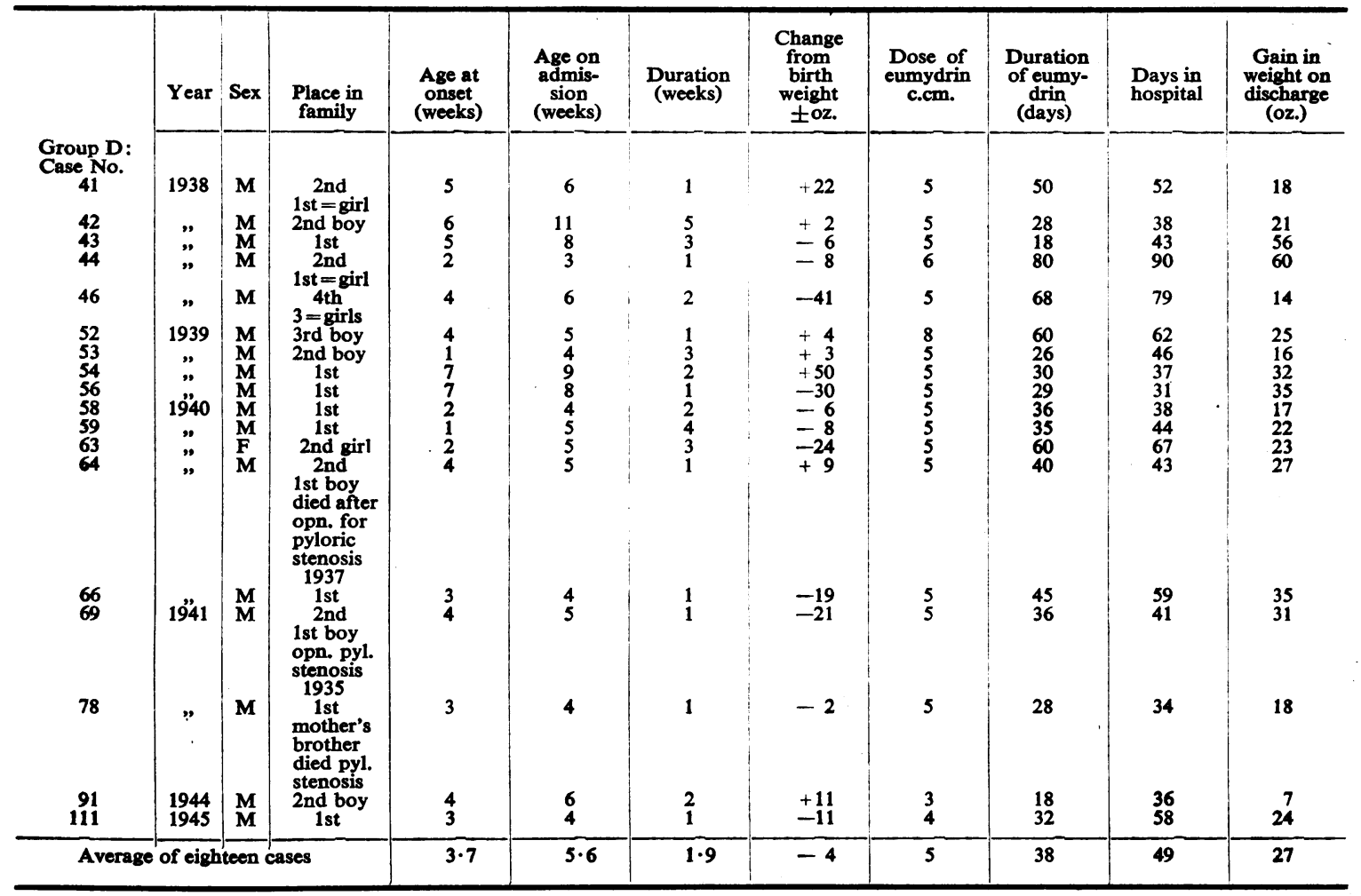

before treatment was begun, but in the other groups there was a loss of weight, and in group D-the six cases who were in hospital over thirty daysthere was an average loss of $21 \mathrm{oz}$. below the birth weight. Nevertheless these cases did respond to eumydrin, although more slowly.

The two cases who were operated upon were in group $C$, and the age of onset of symptoms was two weeks; there was a loss of weight of 12 and $9 \mathrm{oz}$. respectively, and after eight days' trial of eumydrin it was obvious that operative treatment was necessary. This was in no way prejudicial to their ultimate recovery and does not support the contention that there is an added risk in attempting medical treatment before undertaking surgical interference.

Trascentin suppositories were used in cases 27 and 29 in this series, but were not as effective as eumydrin. It was hoped that trascentin would have a longer action than eumydrin thus requiring only two doses a day. In case 27 , two suppositories a day for eleven days sufficed to cure the condition, but in case 29 , owing to inadequate response to trascentin, eumydrin was substituted.

SERIES B. This series comprises seventy-two cases treated over a period of eight years. All the cases were treated with eumydrin, and three cases (numbers 83, 92, and 104) were subjected to Rammstedt's operation after eumydrin had proved ineffective. Two of these three cases died and are discussed later. Case 92, which survived the operation, had a pre-operative trial of eumydrin for seven days. Ten of the seventy-two cases died, and the factors contributing to this fatal outcome are discussed in a later section. The remaining sixty-two cases have been classified into four groups, depending on the length of stay in hospital (table 3).

From this table it can be seen that eighteen out of sixty-two cases, i.e. nearly 30 per cent., were detained in hospital for over thirty days. This long stay in hospital is, from the medical, economic, and social standpoints, undesirable. The causes for this long stay in hospital were as follows: six because of infections, six because of poor home conditions, and six because of slow response to eumydrin; two of these would probably have benefited from surgery.

Deaths. Out of 112 cases, a total of twelve died while under treatment. The deaths are considered separately because it is felt that an analysis of the causes of death might throw some light on the methods for avoiding a fatal outcome in this disease. Table 4 gives in concise form the relevant facts with regard to the twelve deaths.

The most striking feature in all the cases was the 
TABLE 4

ANALYSIS OF THE TWELVE DEATHS

\begin{tabular}{|c|c|c|c|c|c|c|c|c|c|c|c|}
\hline Deaths & Year & Sex & $\begin{array}{l}\text { Place in } \\
\text { family }\end{array}$ & $\begin{array}{c}\text { Age at } \\
\text { onset } \\
\text { (weeks) }\end{array}$ & $\begin{array}{c}\text { Age on } \\
\text { admis- } \\
\text { sion } \\
\text { (weeks) }\end{array}$ & $\begin{array}{c}\text { Dura- } \\
\text { tion } \\
\text { (weeks) }\end{array}$ & $\begin{array}{l}\text { Birth } \\
\text { weight }\end{array}$ & $\begin{array}{l}\text { Weight } \\
\text { on } \\
\text { admis- } \\
\text { sion }\end{array}$ & $\begin{array}{l}\text { Hydra- } \\
\text { tion } \\
+ \\
++ \\
+++ \\
++++\end{array}$ & $\begin{array}{l}\text { Dose of } \\
\text { eumy- } \\
\text { drin } \\
(\mathrm{c.cm} .)\end{array}$ & $\begin{array}{l}\text { Dura- } \\
\text { tion of } \\
\text { eumy- } \\
\text { drin } \\
\text { (days) }\end{array}$ \\
\hline \multirow{2}{*}{$\begin{array}{c}\text { Case No. } \\
60 \\
61\end{array}$} & \multirow{2}{*}{$\begin{array}{l}1940 \\
1940\end{array}$} & \multirow{2}{*}{$\begin{array}{l}\mathbf{M} \\
\mathbf{M}\end{array}$} & \multirow{6}{*}{ 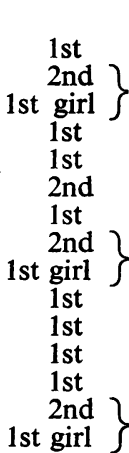 } & 3 & 9 & 6 & $\begin{array}{r}\text { lb. oz. } \\
5\end{array}$ & $\underset{5}{\mathrm{Ib} .} \mathrm{Oz}$ & ++++ & 5 & 11 \\
\hline & & & & 2 & 3 & 1 & 66 & 60 & +++ & 5 & 14 \\
\hline \multirow[t]{2}{*}{$\begin{array}{l}71 \\
72 \\
17 \\
20 \\
83\end{array}$} & \multirow[t]{2}{*}{$\begin{array}{l}1941 \\
1941 \\
1942 \\
1942 \\
1944\end{array}$} & \multirow[t]{2}{*}{$\begin{array}{l}\mathbf{M} \\
\mathbf{M} \\
\mathbf{M} \\
\mathbf{M} \\
\mathbf{F}\end{array}$} & & $\begin{array}{l}4 \\
2 \\
1 \\
7\end{array}$ & $\begin{array}{r}5 \\
4 \\
7 \\
12\end{array}$ & $\begin{array}{l}1 \\
2 \\
6 \\
5\end{array}$ & $\begin{array}{lr}7 & 12 \\
9 & 12 \\
5 & 3 \\
5 & 14\end{array}$ & $\begin{array}{rr}7 & 7 \\
6 & 10 \\
4 & 12 \\
7 & 3\end{array}$ & $\begin{array}{r}+++ \\
+++ \\
++++ \\
++++\end{array}$ & $\begin{array}{l}5 \\
5 \\
5 \\
5\end{array}$ & $\begin{array}{r}22 \\
33 \\
2 \\
21\end{array}$ \\
\hline & & & & 2 & 3 & 1 & 70 & 57 & +++ & 4 & 9 \\
\hline $\begin{array}{r}88 \\
96 \\
99 \\
104\end{array}$ & $\begin{array}{l}1944 \\
1945 \\
1945 \\
1945\end{array}$ & $\begin{array}{l}\mathbf{M} \\
\mathbf{M} \\
\mathbf{M} \\
\mathbf{M}\end{array}$ & & $\begin{array}{l}3 \\
4 \\
4 \\
4\end{array}$ & $\begin{array}{l}7 \\
5 \\
6 \\
6\end{array}$ & $\begin{array}{l}4 \\
1 \\
2 \\
2\end{array}$ & $\begin{array}{rr}6 & 0 \\
6 & 4 \\
3 & 12 \\
5 & 8\end{array}$ & $\begin{array}{lr}5 & 0 \\
6 & 2 \\
4 & 12 \\
6 & 5\end{array}$ & $\begin{array}{r}+++ \\
+++ \\
+++ \\
+++\end{array}$ & $\begin{array}{l}3 \\
5 \\
3 \\
5\end{array}$ & $\begin{array}{r}2 \\
24 \\
10 \\
16\end{array}$ \\
\hline 10 & 19. & M & & 4 & 6 & 2 & 60 & 714 & ++ & 5 & 10 \\
\hline
\end{tabular}

degree of dehydration which was present when they were admitted to hospital. Six out of twelve cases were grossly dehydrated $(++++)$, and five of the remaining six cases were severely dehydrated $(+++)$. An infective cause for the dehydration was present on admission in only two cases (cases 96 and 107), and was present in case 20 on the second admission after being treated initially with success by eumydrin. Case 88 was a twin, and case 99 was a seven-weeks premature baby. Thus at least ten of these cases might have been successfully treated surgically if operated upon within twentyfour hours of admission. Rammstedt's operation was performed on two cases (cases 83 and 104) on the ninth and sixteenth day respectively, but this procedure had obviously been employed after too long a delay.

Another feature of these twelve cases was the low birth weights. Nine of the twelve cases weighed less than $6 \frac{1}{2} \mathrm{lb}$. at birth, there being a wide variation from $3 \mathrm{lb} .12 \mathrm{oz}$. to $6 \mathrm{lb} .6 \mathrm{oz}$. The remaining three cases weighed $7 \mathrm{lb}$., $7 \mathrm{lb} .12 \mathrm{oz}$., and $9 \mathrm{lb} .12 \mathrm{oz}$.

Of the total 112 cases in series $A$ and $B$, only eighteen weighed $6 \frac{1}{2} \mathrm{lb}$. or less at birth, and 50 per cent. of this number died.

The age of onset of symptoms, and age when treatment was commenced, showed no variation from the successfully treated cases.

One point which may have a bearing on the successful outcome of operative treatment is shown in case 83. This baby developed bronchopneumonia within twelve hours of the administration of open ether, and died two days later. Local anaesthesia might have tipped the scales in favour of a successful outcome in this case.

\section{Discussion}

A survey of the literature from 1910 to 1944 reveals that the total mortality rate both for medical and surgical treatment is the same, 11.8 per cent. in a series of 4,162 cases medically treated and 3,508 surgically treated. There is, however, a wide variation in the percentage of successful cases. For example, in 1910, Hutchison treated medically sixty-four cases, and fifty died, a mortality rate of 78 per cent.; whereas in 1930 Wolff treated ninetyeight cases medically and two died, a mortality of 2.0 per cent. Again, in 1914, Holt treated twentynine cases surgically, and seventeen died, a mortality rate of 58 per cent., whereas in 1941 Levi treated 100 consecutive cases surgically without a death. Such statistics probably do not reflect favourably upon either form of treatment having regard to the year in which the cases were studied, and the number of workers involved. A better gauge of the relative merits of the two forms of treatment is obtained by a study of the results of workers in the same town or institution.

In 1935 Svensgaard published her results in cases studied from 1911 to 1934 , and divided them into three groups, depending on the type of medical treatment employed. From 1911 to 1927 , seventyone cases were treated by lavage and duodenal tube, and ten died, a mortality of $7 \cdot 1$ per cent. From 1922 to 1927, forty-seven cases were treated with atropine, and three died, a mortality of 6.4 per cent. From 1927 to 1934, sixty-one cases were treated 
with eumydrin and two died, a mortality of $3 \cdot 3$ per cent. In 1937 there was a 10 per cent. mortality from surgical treatment at the Hospital for Sick Children, Great Ormond Street, London; in 1938 the mortality was 9 per cent., and in 19396.5 per cent. Thus with both methods of treatment there has been a fall in the mortality rate, probably resulting from the employment of a definite detailed routine method of treatment for this condition.

The aim of both medical and surgical treatment of pyloric stenosis is to overcome the obstruction to the outflow of food from stomach to duodenum, an obstruction which will relieve itself in time provided that the patient does not die from malnutrition in the process. Both methods aim at hastening this natural process of recovery. Wollstein (1922) has shown from post-mortem material that three or four weeks after division of the circular muscle of the pylorus (Rammstedt's operation) there is hardly any anatomical abnormality to be noted at the pyloric end of the stomach. After medical treatment with antispasmodics, a similar result is obtained, but in a longer time. In case 15 a necropsy two months after clinical cure of the stenosis showed no abnormality of the pyloric muscle.

Thus, although the aim of both medical and surgical treatment is the same, there are certain guiding principles which determine the type of treatment employed and, in addition, there are certain general principles of treatment which are common to both the medical and surgical methods.

1. All cases of pyloric stenosis should be treated in single wardlets or cubicles. This is an important measure to ensure that the chance of cross-infection is cut to a minimum. Private cases invariably do better than hospital cases, and this is largely due to the greater risk of cross-infection in hospital, even with babies nursed in single cubicles.

2. All cases should be breast fed if at all possible, because the results in breast-fed babies are far better than in those artificially fed. The excellent results obtained by Levi (1941), who operated on one hundred breast-fed babies without a death, may be quoted in support of this statement. Of the twelve deaths in the present series of 112 cases, only two were breast fed, seven were fed entirely on artificial foods, and three were fed on artificial foods after the tenth day. All observers are agreed that the mortality rate from diarrhoea and vomiting (socalled gastro-enteritis) is markedly higher in bottlefed babies, so it is important in pyloric stenosis to encourage breast feeding because infection is so prone to occur in this condition. Several cases in this series were taken into hospital to re-establish breast feeding and not because of the severity of the pyloric stenosis, which could have been treated in the out-patient department.

In the choice of medical or surgical treatment the following three criteria are important guides.

Experience of the method. It cannot be emphasized too often that in the treatment of this condition special nursing experience is essential, and it is probably true to say that it is far more important to have a good ward sister than a good house physician. I readily agree with Paterson (1941) that it would be giving the medical profession an entirely wrong idea if it were thought that all cases of pyloric stenosis could be cured if put on a properly regulated dose of eumydrin: too much stress has been placed on the action of the drug, and too little stress on the careful nursing and feeding management. Bitter experience has shown how the response to treatment varies when a competent sister is on holiday.

Again, in surgical treatment, the experience of the surgeon is of vital importance. The surgical treatment of pyloric stenosis should be undertaken only by a surgeon experienced in this particular operative procedure.

Availability of treatment. In large towns where competent surgical assistance is available, the general bias is towards operative treatment. Provided that a careful technique is worked out in the light of experience, the results are satisfactory. In country districts where experienced surgeons may not be available, and in private practice, antispasmodic treatment will give good results. 'Babies living in the country can be adequately and successfully treated as out-patients attending the paediatric clinic once a week. Length of stay in hospital is an important factor, because each day brings an added risk of infection, and out-patient treatment with eumydrin overcomes this difficulty.

Special indications for each method. Various writers have formulated criteria which broadly indicate when medical or surgical treatment should or should not be employed. The most comprehensive criteria are those of Jacoby (1944 and 1946) who summarized these indications (table 5). The main points stressed are: (1) age of onset of vomiting; (2) duration of vomiting; (3) degree of dehydration; (4) presence of infection.

1. In thirty-four patients in the present series the vomiting began during the second week or earlier, and in thirty patients vomiting began after the fourth week. This leaves forty-eight of the 112 patients, i.e. 43 per cent., to which one of Jacoby's indications cannot be applied. If this criterion is applied to the cases that died-and all 
TABLE 5

CRITERIA FOR MEDICAL AND SURGICAL TREATMENT, ACCORDING TO JACOBY

\begin{tabular}{ll|l|l|l}
\hline & \multicolumn{1}{|c|}{ Surgical treatment } & \multicolumn{1}{c}{ Medical treatment } \\
\hline Indications & $\ldots$ &. & $\begin{array}{l}\text { (a) Vomiting beginning in the second week } \\
\text { or earlier. } \\
\text { (b) Severe dehydration. }\end{array}$ & $\begin{array}{l}\text { (a) Vomiting starting in the fourth week or } \\
\text { later. } \\
\text { (b) Vomiting continuous for three weeks or } \\
\text { more, before the infant is first seen, } \\
\text { provided it is not severely dehydrated. }\end{array}$ \\
\hline Contra-indications & $\ldots$ & $\begin{array}{l}\text { (a) Infection. } \\
\text { (b) Diarrhoea. }\end{array}$ & $\begin{array}{l}\text { (a) Severe dehydration. } \\
\text { (b) Haematemesis. }\end{array}$ \\
\hline
\end{tabular}

these indications are guides to the achievement of a low mortality rate-we find that in six of the twelve deaths the vomiting began in the fourth week or later, and thus from this point of view the treatment should have been, and was, medical; in four patients vomiting began in the second week or earlier, and thus surgical treatment should have been employed.

2. In only twenty-seven cases out of 112 was the vomiting continuous for three weeks or more before the patients were first seen; and of the twelve deaths the duration of vomiting was three weeks or more in four, in four cases it was for one week only, and in four cases it lasted for two weeks. Thus again the treatment in only four of the patients who died should have been altered if this criterion of Jacoby's is to be accepted, whereas a further twenty-three cases who were cured medically should have been subjected to surgery.

3. It is difficult to know what is meant by ' severe dehydration,' but those cases requiring salines for eight days or more can be considered to be severely dehydrated. The following figures show the state of dehydration of the 112 cases as judged by the duration of subcutaneous salines:

Cases not requiring saline: out-patients 10 " ," in-patients 34 Cases requiring saline for 1 to 7 days: 31

$" \quad \quad " \quad$ " $\quad$ " $\quad$ over $14, " \quad 14$

Of the twelve deaths, nine were severely dehydrated but a.further twenty-eight cases, though dehydrated, recovered with medical treatment.

4. Infection of a severe degree did not occur in the cases in this series, and there were no cases heavily infected on admission. There were, however, thirteen mild cases of B. coli pyelitis, but these quickly recovered with potassium citrate and in some cases sulphonamides in addition. I agree, however, with Jacoby that in infected cases surgery is best avoided.

Having considered these criteria, we are now in a position to judge if they are of any value in deciding which cases shall receive medical, and which surgical treatment. Table 6 is a summary of Jacoby's criteria applied to these 112 cases. This summary shows that the average age of onset of vomiting varied very little in any of the groups, and certainly no sign of prognostic value is apparent from a knowledge of the time of onset of symptoms. There is an even more striking uniformity in the duration of vomiting in all groups, with the exception of group $E$ (the out-patient cases), so that no prognostic value can be attached to this observation. The loss of weight also bore no relationship to the severity of the disease, and the amount of infection was equally distributed among all groups except group $\mathrm{E}$.

The severity of dehydration was an important factor, the most severely dehydrated babies either dying or having a long stay in hospital.

Having thus analysed the factors which may determine the successful treatment of these cases of infantile pyloric stenosis, we are in a position to formulate certain criteria which will enable a decision to be taken as to which form of treatment, medical or surgical, should be employed in a particular patient with this disease.

1. Medical treatment should be the routine method of treatment for congenital pyloric stenosis in babies who are not severely dehydrated.

2. If medical treatment is ineffective after a trial of seven days, Rammstedt's operation should be undertaken without delay, provided the baby is not grossly infected.

3. Obvious infection in the baby is a contraindication to surgical treatment.

4. Gross dehydration is an indication for surgical treatment.

5. Surgical treatment should be employed in babies whose birth weight was below $6 \frac{1}{2} \mathrm{lb}$.

\section{Follow-up}

After intervals of time varying from eleven to thirty-two months, these cases of pyloric stenosis were readmitted to hospital for one night for barium meal examination.

The details of the child's history were obtained and the following routine questions were asked: (1) diet (breast or bottle, weaning, cod-liver oil and orange juice); (2) development (first tooth, sitting up, standing, walking, talking); (3) subsequent illnesses (especially gastric symptoms, e.g. vomiting, 
TABLE 6

SUMMARY OF JACOBY'S CRITERIA APPLIED TO THE 112 CASES IN THE PRESENT SERIES

\begin{tabular}{|c|c|c|c|c|c|c|c|}
\hline Series & Group & $\begin{array}{l}\text { Number of } \\
\text { cases }\end{array}$ & $\begin{array}{c}\text { Average age of } \\
\text { onset of } \\
\text { vomiting }\end{array}$ & $\begin{array}{l}\text { Duration of } \\
\text { vomiting } \\
\text { before } \\
\text { treatment }\end{array}$ & $\begin{array}{c}\text { Change from } \\
\text { birth } \\
\text { weight }\end{array}$ & $\begin{array}{l}\text { Number of } \\
\text { infected } \\
\text { cases }\end{array}$ & $\begin{array}{c}\text { Severely } \\
\text { dehydrated }\end{array}$ \\
\hline $\begin{array}{c}\text { A } \\
\text { B } \\
\text { Deaths }\end{array}$ & $\begin{array}{l}\mathbf{A} \\
\mathbf{B} \\
\mathbf{C} \\
\mathbf{D} \\
\mathbf{E} \\
\mathbf{A} \\
\mathbf{B} \\
\mathbf{C} \\
\mathbf{D}\end{array}$ & $\begin{array}{r}5 \\
9 \\
8 \\
6 \\
10 \\
11 \\
20 \\
13 \\
18 \\
12\end{array}$ & $\begin{array}{l}\text { weeks } \\
4 \\
3 \cdot 3 \\
3 \\
3 \cdot 1 \\
4 \cdot 2 \\
3 \cdot 6 \\
3 \cdot 6 \\
4 \cdot 2 \\
3 \cdot 7 \\
3 \cdot 5\end{array}$ & $\begin{array}{c}\text { weeks } \\
2.2 \\
1.8 \\
1.0 \\
1.7 \\
4.0 \\
2.4 \\
1.8 \\
1.8 \\
1.9 \\
2.5\end{array}$ & $\begin{array}{l}\text { oz. } \\
-12 \\
-5 \\
-7 \\
-21 \\
+16 \cdot 5 \\
-1 \cdot 3 \\
-9 \\
-4 \\
-4 \\
-6\end{array}$ & $\begin{array}{l}2 \\
2 \\
2 \\
2 \\
0 \\
2 \\
3 \\
3 \\
6 \\
3\end{array}$ & $\begin{array}{l}0 \\
2 \\
6 \\
4 \\
0 \\
0 \\
2 \\
6 \\
8 \\
9\end{array}$ \\
\hline
\end{tabular}

anorexia, abdominal pain); (4) psychological (unrest, anxiety; temperament); (5) mental organization (playing interests, etc.); (6) family (other cases of pyloric stenosis); (7) height and weight.

Series A. The child was given a full clinical examination, and in none of the cases was there any evidence of organic disease. In no case had the pyloric stenosis hindered the subsequent development of the child. Each child was given a barium meal, and the routine preparation for this was starvation for nine hours, nothing by mouth from 12 midnight until 9 a.m. when the barium was given. At 9 a.m. the child was taken to the x-ray department and given four teaspoonfuls of barium emulsion; the child was then screened and the first film taken. Four or five additional spoonfuls of barium emulsion were then swallowed, and the child taken back to the ward. At 12 noon, i.e. three hours later, the child was again taken to the $\mathrm{x}$-ray department for further screening, and the final film taken. Particular notice was taken of any deformity of the pyloric region, and of any delay in emptying time. Table 7 summarizes the results of the barium meals in Series A. This table shows that in group A

TABLE 7

RESULTS OF BARIUM MEAL IN SERIES

\begin{tabular}{c|c|c|c|c}
\hline Group & $\begin{array}{c}\text { No. of } \\
\text { cases }\end{array}$ & $\begin{array}{c}\text { Emptying } \\
\text { not } \\
\text { delayed }\end{array}$ & $\begin{array}{c}\text { Slight } \\
\text { delay }\end{array}$ & $\begin{array}{c}\text { Definite } \\
\text { delay }\end{array}$ \\
\hline A & 4 & $4(100 \%)$ & - & - \\
B & 7 & $5(71 \%)$ & $2(29 \%)$ & - \\
C & 7 & $1(14 \%)$ & $3(43 \%)$ & $3(43 \%)$ \\
D & 6 & $4(66 \%)$ & $1(17 \%)$ & $1(17 \%)$ \\
E & 10 & $6(60 \%)$ & $3(30 \%)$ & $1(10 \%)$ \\
\hline
\end{tabular}

(those cases under ten days in hospital) all the four cases examined had no delay in emptying, no barium remaining in the stomach three hours after the commencement of the barium meal. In group B (cases in hospital from eleven to twenty days), five of the seven cases showed no delay in emptying, the remaining two cases showing only slight delay. In group $C$ (cases in hospital twenty-one to thirty days), there was slight delay in three of the seven cases, and definite delay in three of the seven cases. In group $\mathbf{D}$ (cases in hospital over thirty days) there was no delay in emptying in four of the six cases. In group $\mathbf{E}$ (out-patient series) there was no delay in six of the ten cases, slight delay in three cases, and definite delay in one case. Thus it is seen that in groups $\mathrm{A}, \mathrm{B}$, and $\mathrm{C}$, the degree of delay was roughly proportional to the length of stay in hospital; the more pronounced the delay, the longer the cases were in hospital, and, since the length of stay in hospital in most cases reflected the severity of the disease, the delay in emptying time was an indication of the severity of the pyloric stenosis.

Group D, at first sight, does not fit into the general pattern, but on closer investigation it was found that three of the four cases showing no delay on x-ray examination were detained in hospital longer than the severity of the symptoms required, for the following reasons. Case 2 had a very nervous mother, and an attempt was made to re-establish breast feeding in this case. The eumydrin was stopped four days before discharge, and the condition had cleared up satisfactorily and the mother educated in mothercraft before the child was allowed to leave hospital. In case 3 the home conditions were extremely poor, and it was for this reason that the child remained longer in hospital than was necessary. Eumydrin was discontinued ten days before this child was discharged. For similar reasons case 7 remained in hospital longer 
than the disease process warranted. The gain in weight of $20 \mathrm{oz}$. during the last twenty-eight days of hospital treatment supports the contention.

Thus Series A shows that there is a close relationship between the severity of the pyloric stenosis and the subsequent radiological findings from one to two and a half years later.

Series B. Of the total of seventy-two cases in this series, twenty-six were seen at the follow-up examination. Of the remaining forty-six cases, ten had died of pyloric stenosis, twelve did not attend the follow-up clinic, and twenty-four were considered to be too young for a follow-up examination to be profitable. (Their ages varied from four months to twenty months.) The routine questions asked were similar to those used at the follow-up of the cases in Series A. Clinical examination did not reveal any abnormalities, and height and weight measurements were within normal limits in all cases. Table 8 summarizes the relevant results with regard to symptoms.

Nine of the twenty-six patients had symptoms referable either directly or indirectly to the abdominal tract. These nine cases were given barium meals in order to determine if there were

TABLE 8

SUMMARY OF FOLLOW-UP FINDINGS IN SERIES B

\begin{tabular}{c|c|c}
\hline Year & $\begin{array}{c}\text { Case } \\
\text { no. }\end{array}$ & \multicolumn{2}{|c}{ Symptoms } \\
\hline 1938 & 45 & $\begin{array}{c}\text { Epigastric pain after food; constipa- } \\
\text { tion }\end{array}$ \\
\hline 1939 & 51 & $\begin{array}{c}\text { Occasional vomiting, probably due to } \\
\text { post-nasal catarrh }\end{array}$ \\
\hline 1940 & 54 & Bowels open after each meal \\
\hline 1941 & 74 & $\begin{array}{c}\text { 'Bilious attacks ': vomiting, headache, } \\
\text { temperature, and abdominal pain }\end{array}$ \\
\hline 1942 & 79 & $\begin{array}{c}\text { Abdominal pain and vomiting fre- } \\
\text { quently }\end{array}$ \\
\hline 78 & $\begin{array}{c}\text { Bilious attacks ': vomiting, headache, } \\
\text { temperature, and abdominal pain }\end{array}$ \\
\hline
\end{tabular}

any visible results of infantile pyloric stenosis. ' In addition two other cases (numbers 43 and 57) were examined radiologically. The radiological findings were as follows: (a) cases $43,51,55,74,78$, and 79 showed no contraction of the pyloric area and no delay in emptying time; (b) cases 57 and 54 showed slight contraction at the pyloric antrum, but no delay in emptying time; (c) case 45 showed definite contraction of the pyloric antrum but no delay in emptying time; (d) case 64 showed a fair amount of contraction of the pyloric area with spasm, but no delay in emptying time; (e) case 68 showed definite contraction of the pyloric antrum, and emptying was slower than in a normal case, though there was no extensive delay.

Of the five cases showing some abnormality of the barium meal, two belonged to group B (eleven to twenty days in hospital), and three belonged to group D (over thirty days in hospital). These findings tend to support the conclusions drawn from the results of barium meal examination in Series A, namely that the more severe the case of pyloric stenosis as judged by length of stay in hospital, the more there is a likelihood of permanent structural damage to the pyloric area. No definite conclusions can, however, be drawn from the small number of barium examinations carried out upon Series B, but these results tend to support the thesis advanced for Series A.

\section{Conclusions}

1. One hundred and twelve cases of congenital hypertrophic pyloric stenosis treated medically are presented. Series A comprises forty consecutive cases, with two deaths, and Series B comprises seventy-two cases treated at the same hospital over an eight-year period, with ten deaths.

2. Particular stress is laid on the observance of a definite routine, whichever method of treatment is employed.

3. The cases in Series A were followed up clinically and radiologically. Their subsequent physical and mental development was in no way affected by the pyloric stenosis, but the delay in emptying time of the stomach when seen at the follow-up examination was proportional to the severity of the condition as judged by the length of hospital treatment.

4. The cases in Series B were followed up clinically, and some were submitted to radiological examination. The results tend to confirm those of Series A.

5. The following criteria are useful in deciding which method of treatment should be employed in a particular case of congenital pyloric stenosis: (a) medical treatment should be the routine method of treatment unless the patient is grossly dehydrated; (b) surgical treatment should be undertaken if medical treatment is ineffective after a seven-day trial, unless the patient has any infection; (c) 
surgical treatment is indicated in patients who are grossly dehydrated when first seen, or in whom the birth weight was below $6 \frac{1}{2} \mathrm{lb}$.; (d) surgical treatment is contra-indicated in any infected patient because of the risk of fatal ' gastro-enteritis.'

My thanks are due to Dr. J. V. C. Braithwaite for his guidance and interest, to Dr. D. Forbes Lawson for the X-ray examinations, and to Sister Maud E. Williams for her invaluable co-operation.
Dobbs, R. (1941). Proc. roy. Soc. Med., 35, 51. Holt, L. E. (1914). J. Amer. med. Ass., 62, 2014. Hutchison, R. (1910). Brit. med. J., 2, 1021. Jacoby, N. M. (1944). Lancet, 2, 748. (1946). Brit. med. J., 1, 721. Levi, D. (1941). Ibid., 1, 964.

Mackay, H. M. M. (1941). Arch. Dis. Childh., 16, 1. Paterson, D. (1941). Proc. roy. Soc. Med., 35, 49. Svensgaard, E. (1935). Arch. Dis. Childh., 10, 443. Wolff, S. (1930). Jahrb. Kinderheilk., 128, 287.

Wollstein, M. (1922). Amer. J. Dis. Child., 23, 511. 